\title{
MEASURING THE DEVELOPMENT OF THE HUNGARIAN ELECTRONIC ADMINISTRATION
}

\author{
Anna Orbán ${ }^{1}$
}

DOI: 10.24989/ocg.v.338.7

\begin{abstract}
The creation of electronic administration and the measurement of the results achieved have been one of the central themes of research into the development of the information society for two decades. The European Commission publishes annually e-government comparative analyses (eGovernment Benchmark reports), providing insight into the use of ICT in the public sector in the countries examined.

In recent years, the measuring system has been modified and supplemented several times. The Digital Economy and Society Index (DESI) and the benchlearning approach assess the performance of eadministration on the basis of additional considerations. Hungary's performance is improving, but still below the EU average. Exploring the causes of the underperformance is a priority for catching up.

On the basis of a survey of students at the National University of Public Service, the author analyses user characteristics (digital skills, ICT use) and the characteristics of public administration (quality of electronic administration services) in their context.
\end{abstract}

Keywords: electronic administration, performance measurement, benchmarking, DESI, benchlearning

\section{Introduction}

The European Union has examined the implementation of its strategies and programmes from the outset by means of indicators, comparing Member States' performance (rankings), highlighting the best-qualified (best practice) model.

In March 2000, the European Council adopted the Lisbon Strategy ${ }^{2}$, based on guidelines and recommendations, which aims to make Europe the most competitive and dynamic knowledge-based society in the world by 2010. [11]

The tasks of developing the information society were formulated on the basis of the eEurope initiative launched in 1999. [9] Action plans (eEurope 2002 [10], eEurope 2005 [12], i2010 [14]) have been developed to achieve these goals.

\footnotetext{
${ }^{1}$ National University of Public Service, 2 Ludovika sqr., H-1083 Budapest, Hungary, e-mail: orban.anna@uni-nke.hu

${ }^{2}$ The mid-term evaluations [29] [25] have already highlighted the errors and relaunched the strategy in 2005. [13] On the basis of the competitiveness reports, new substantive changes were made in 2008. [4] [5]
} 
The strategic goals were intended to be achieved through open coordination ${ }^{3}$ and benchmarking ${ }^{4}$ methods, which is a simple and useful tool for comparing Member States, but has the disadvantage of focusing too much on benchmarks and ignoring national, territorial specificities.

Initially, the evaluation of electronic public services focused on online preparedness, infrastructure, provision and use of customer-side services [8], and was gradually supplemented with other indicators (e.g. customer experience, life events, service background).

The Europe 2020 Strategy has been developed on the basis of the lessons of the Lisbon Strategy. The aim of the renewed strategy has been to overcome the crisis, to achieve a smart, sustainable and inclusive economy, with stronger governance. [16]

One of the seven main objectives is to disseminate the accessibility and use of information and communication technologies, to improve their quality and to create a digital single market. The necessary measures for smart, sustainable and inclusive growth are set out in the Digital Agenda for Europe. [15] [18]

In line with the change in strategic goals, the performance measurement framework has also been transformed. The development of the information society is illustrated by more than 100 selected indicators, including a comparison of eGovernment performance over time and between Member States. In 2015, the implementation of the European Digital Single Market was a high priority [19], and a new measurement framework, the Digital Economy and Society Measurement System, was developed to monitor strategic goals.[21]

The study further illustrates the measurability of eGovernment development through data from Hungary on the basis of various international indicators.

\section{2. eGovernment Benchmark reports}

E-government benchmarking over the past decade ${ }^{5}$ has assessed the accessibility, quality and usability of e-government services in four main areas. The four complex indicators are calculated on the basis of the weighted averages of several sub-indicators.

An important element of the evaluation system is the Mystery Shopping and the examination of the life event (starting a business, losing and finding job, studying, family life, business operations, moving, owning and driving a car, starting a small claim procedure). In the odd and even years, different life situations are examined, leading to delays in the appearance of results. Time is an important factor in evaluating data, and due to methodological changes, data may not always be comparable.[7]

\footnotetext{
${ }^{3}$ The main components of this method are: definition of directives; the development of quantitative and qualitative indicators; comparison of Member States, sectors and best practices; taking into account national specificities; regular monitoring and evaluation of the results achieved in the framework of the mutual learning processes. [11 pp. 37-38]

${ }^{4}$ Benchmarking is a tool for continuously monitoring progress and evaluating the situation, allowing you to compare performance levels qualitatively and quantitatively, and thus to rank. It is an important tool for learning about best practices that can lead to higher performance in line with your goals. [27]

${ }^{5}$ The measurement framework has changed several times in line with eGovernment action plans (2011-2015, 2016-2020).

[17] [20] [22] [23]
} 
The four key indicators and their components are:

- $\quad$ User centricity: online availability, usability, and (from 2016) mobile friendship.

- Transparency: provision of services, control of public organizations and personal data.

- Cross-border mobility: online accessibility, usability, and (two key factors from 2016) crossborder use of electronic identification (eID) and authentic electronic documents (eDocument).

- Key enablers: electronic identification (eID), authentic electronic documents (eDocument), authentic data sources and (from 2016) digital post (digital storage). ${ }^{6}$

\begin{tabular}{|c|c|c|c|c|c|c|c|c|c|c|c|c|}
\hline $\begin{array}{l}\text { Top Level } \\
\text { Benchmarks }\end{array}$ & \multicolumn{2}{|c|}{$2012+2013$} & \multicolumn{2}{|c|}{$2013+2014$} & \multicolumn{2}{|c|}{$2014+2015$} & \multicolumn{2}{|c|}{$2015+2016$} & \multicolumn{2}{|c|}{$2016+2017$} & \multicolumn{2}{|c|}{$2017+2018$} \\
\hline & $\mathrm{HU}$ & EU & $\mathrm{HU}$ & EU & $\mathrm{HU}$ & EU & $\mathrm{HU}$ & EU & $\mathrm{HU}$ & EU & $\mathrm{HU}$ & EU \\
\hline User centricity & 45 & 70 & 46 & 73 & 53 & 77 & 68 & 80 & 68.8 & 82.8 & 78.8 & 84.8 \\
\hline Transparency & 23 & 48 & 25 & 51 & 27 & 55 & 26 & 59 & 32.8 & 58.6 & 47.3 & 62.3 \\
\hline $\begin{array}{l}\text { Cross-border } \\
\text { mobility }\end{array}$ & 17 & 44 & 24 & 58 & 24 & 55 & & & & & & \\
\hline Citizen & & & & & & & 40 & 61 & 13.3 & 47.8 & 15.3 & 47.5 \\
\hline Business & & & & & & & 30 & 65 & 37.5 & 61.0 & 49.0 & 63.0 \\
\hline Key enablers & 30 & 49 & 30 & 50 & 20 & 54 & 33 & 52 & 46.5 & 53.5 & 62.6 & 58.3 \\
\hline
\end{tabular}

Table 1: Hungarian e-government development compared to EU28+ average values

Source: National Interoperability Framework Observatory (NIFO) [28], own edition

The data generally show progress, although the performance of Hungarian e-administration is lagging behind the EU average. Hungary shows the worst result in the provision of cross-border services to EU citizens ${ }^{8}$. The Hungarian e-administration outperformed the EU average, which is mainly due to the $100 \%$ value of digital post (storage) services. We are still lagging behind in the area of transparency, although the control of personal data has improved significantly. Differences in interpretation, methodological changes and scoring of different life event can lead to contradictory results (e.g. key enablers 20, cross-border services for citizens 40). Although aggregations involve a significant loss of information, examination of detailed data can reveal problematic areas.

\section{Digital Economy and Society Index (DESI)}

Since 2015, the Digital Economy and Society Index (DESI) has been introduced to measure the progress of the Digital Agenda. The five main dimensions of DESI are subdivided into over 30 indicators ${ }^{9}$. [24]

According to the aggregate index Hungary is one of the poorly performing countries, despite the developments in recent years it ranks $23 \mathrm{rd}$. The level of network interconnection is slightly above the EU average. The use of Internet services shows fluctuations. Social networking is outstanding, but

\footnotetext{
${ }^{6}$ Modified indicators: ease of use, speed of use, secure electronic storage (eSafe) and single sign-on (SSO)

7 The benchmark estimates that a country's performance is insufficient between $0-25 \%$, moderate between $25-50 \%$, fair between $50-75 \%$ and good over $75 \%$.

${ }^{8}$ Although one of the objectives of the digital state is: "by 2018 citizens and enterprises should be able to manage all their public administration affairs electronically (where the nature of the process allows it, including cross-border management of affairs as well);" [26 pp. 81]

${ }^{9}$ DESI's methodology, indicator system and weighting of indicators have also changed year on year.
} 
online voting, learning, banking and shopping are low. Hungary has the worst results in terms of digital technology integration and digital public services.

\begin{tabular}{|l|c|c|c|c|c|c|}
\hline Dimension & 2014 & 2015 & 2016 & 2017 & 2018 & 2019 \\
\hline Connectivity & 17. & 17. & 14. & 15. & 15. & 14. \\
\hline Human Capital & 19. & 18. & 18. & 18. & 19. & 20. \\
\hline Use of Internet & 18. & 15. & 13. & 14. & 17. & 18. \\
\hline Integration of Digital Technology & 24. & 25. & 24. & 24. & 24. & 25. \\
\hline Digital Public Services & 22. & 26. & 27. & 27. & 26. & 26. \\
\hline DESI & 22. & 21. & 20. & 23. & 23. & 23. \\
\hline
\end{tabular}

Table 2: Corrected ranks of Hungary ${ }^{10}$ in DESI dimensions

Source: https://digital-agenda-data.eu/datasets/desi), own edition

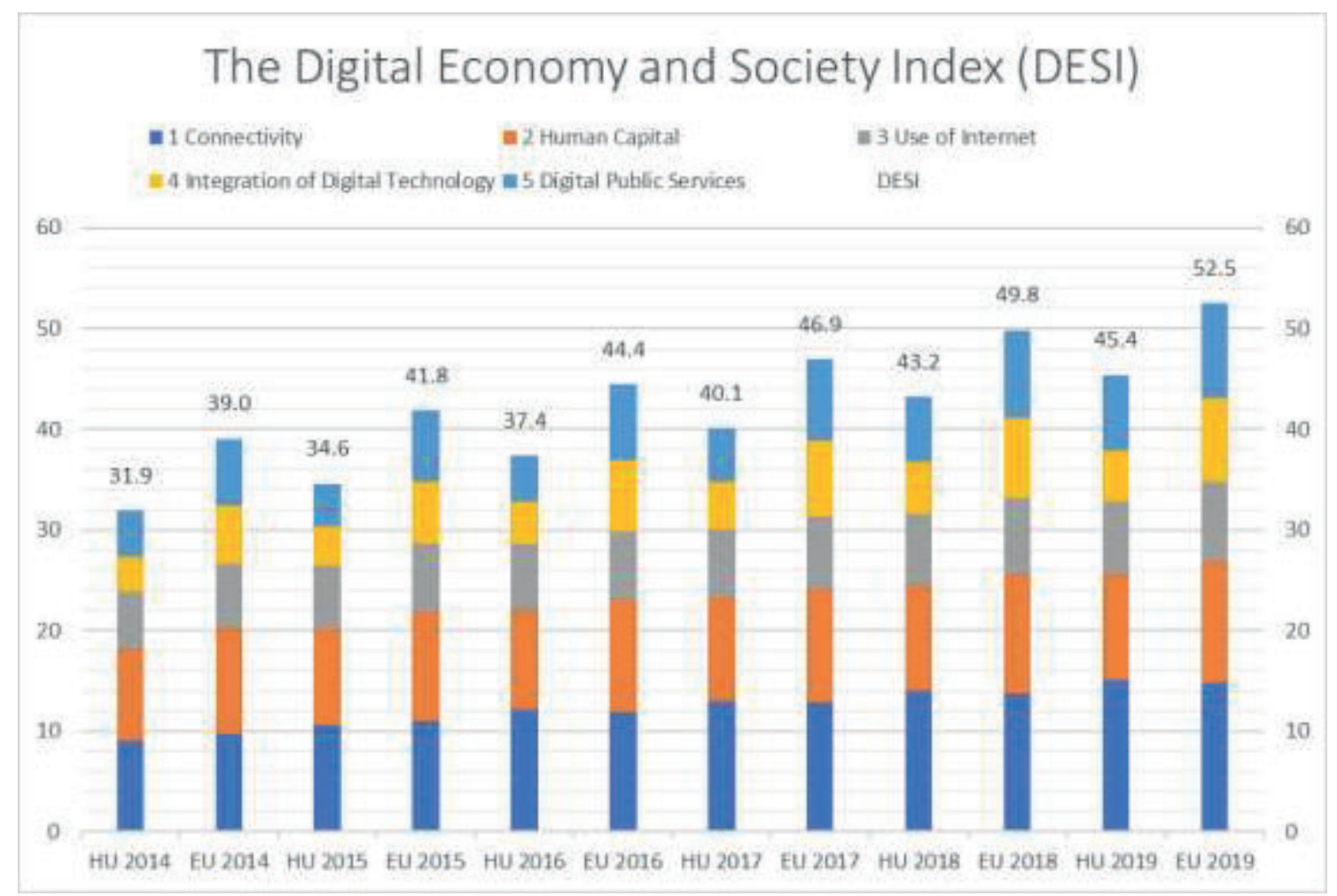

Figure 1: Change in time based on the values of Hungary and EU28 DESI

Source: https://digital-agenda-data.eu/datasets/desi, own edition

Among the digital public services, the performance of the Hungarian e-administration is improving, but it is still below expectations. With regard to open access data, the data source has changed since 2017, and Hungarian values are no longer known in recent reports. In the field of eHealth, the impact of launching the National eHealth Infrastructure (EESZT) has already appeared in 2019, but citizens' access to eHealth services is still low.

The main advantage of DESI is the ability to produce international comparisons and benchmarking at the level of dimensions, subdimensions and indicators. The methodological differences, the topicality of the data (use of earlier data), and the subsequent corrections are the disadvantages of the measuring system. ${ }^{11}$

\footnotetext{
${ }^{10}$ Recalculated based on update and adjustments for metrics, so the rankings published in the annual reports have also changed.

${ }^{11}$ For more information on the analysis of the measuring system, see [1] [2] [6] [7]
} 
The benchlearning approach: clustering of countries to drive learning

The benchlearning approach is used to link the assessment of eGovernment performance with the mutual learning process. The method used since 2015 compares countries with similar environmental characteristics.

The performance of eGovernment is measured through two main dimensions (absolute indicators). Penetration shows the availability of online eGovernment services. The degree of digitization (as an average of 4 indicators) is the level of digitization of administrative front office and back office processes. It is possible to highlight the relationship between these indicators. The analysis also covers influencing external factors (relative indicators): user characteristics (digital skills, ICT usage), administrative characteristics (quality of public administration services, openness) and characteristics of the digital environment (interconnection, digitalisation of the private sector).

Hungary was still a progressive group ${ }^{12}$ based on 2012-2013 data, but has been reclassified as a highpotential country ${ }^{13}$ in the following years. Despite developments, Hungary still belongs to the nonconsolidated eGovernment group based on low-level digitization and medium-low penetration.

\begin{tabular}{|c|c|c|c|c|c|c|c|c|}
\hline & \multicolumn{2}{|c|}{ Performance (Absolute) } & \multicolumn{6}{|c|}{ Environment characteristics (Relative) } \\
\hline & \multirow{2}{*}{ Penetration } & \multirow{2}{*}{ Digitisation } & \multicolumn{2}{|c|}{$\begin{array}{c}\text { User } \\
\text { characteristics }\end{array}$} & \multicolumn{2}{|c|}{$\begin{array}{c}\text { Government } \\
\text { characteristics }\end{array}$} & \multicolumn{2}{|c|}{ Context characteristics } \\
\hline & & & $\begin{array}{l}\text { Digital } \\
\text { Skills }\end{array}$ & $\begin{array}{c}\text { ICT } \\
\text { usage }\end{array}$ & Quality & Openness & Connectivity & $\begin{array}{c}\text { Digital in } \\
\text { private sector }\end{array}$ \\
\hline 2017 EU28 & $52 \%$ & $65 \%$ & $51 \%$ & $48 \%$ & $71 \%$ & $59 \%$ & $60 \%$ & $35 \%$ \\
\hline $2017 \mathrm{HU}$ & $31 \%$ & $41 \%$ & $44 \%$ & $51 \%$ & $58 \%$ & $55 \%$ & $60 \%$ & $21 \%$ \\
\hline 2018 EU28 & $53 \%$ & $63 \%$ & $55 \%$ & $53 \%$ & $71 \%$ & $72 \%$ & $64 \%$ & $41 \%$ \\
\hline $2018 \mathrm{HU}$ & $35 \%$ & $42 \%$ & $48 \%$ & $54 \%$ & $57 \%$ & $53 \%$ & $62 \%$ & $25 \%$ \\
\hline 2019 EU28 & $57 \%$ & $68 \%$ & $49 \%$ & $53 \%$ & $70 \%$ & $68 \%$ & $60 \%$ & $42 \%$ \\
\hline $2019 \mathrm{HU}$ & $42 \%$ & $56 \%$ & $42 \%$ & $48 \%$ & $57 \%$ & $\mathrm{n} / \mathrm{a}$ & $60 \%$ & $25 \%$ \\
\hline
\end{tabular}

Table 3: Benchlearning indicators in Hungary compared to the EU average Source: eGovernment Benchmark 2017, 2018, 2019 [3] own edition

Although the level of network connectivity is good, most indicators are below the EU average, and the country is still below the EU average in terms of digitization and penetration. There is a greater lag in digitization in the private sector and data of openness are unknown in 2019.

\section{Examining the influencing factors (questionnaire survey among student)}

The survey conducted among the students of the National University of Public Service Faculty of Political Governance and International Studies focuses on the use of ICT, Internet services and egovernment services. The questionnaire was completed by 494 people.

Respondents have internet access: $88.1 \%$ with fixed broadband, $75.7 \%$ with mobile broadband. Only 3 people have no internet access at home. The Internet is used daily, often all day (99\%). Smartphones $(99.2 \%)$ and tablets $(92.3 \%)$ are mostly used to access the Internet. Only 2 people have not used a mobile device.

\footnotetext{
${ }^{12}$ Medium-level penetration and medium-level digitisation

${ }^{13}$ Medium-level penetration and low digitisation
} 
Internet, e-mail, messaging and social networking are outstanding, but there is a low level of published public and political opinion. The low level of use of e-learning and blended learning courses was surprising, as the university uses an e-learning framework for both undergraduate and graduate courses.

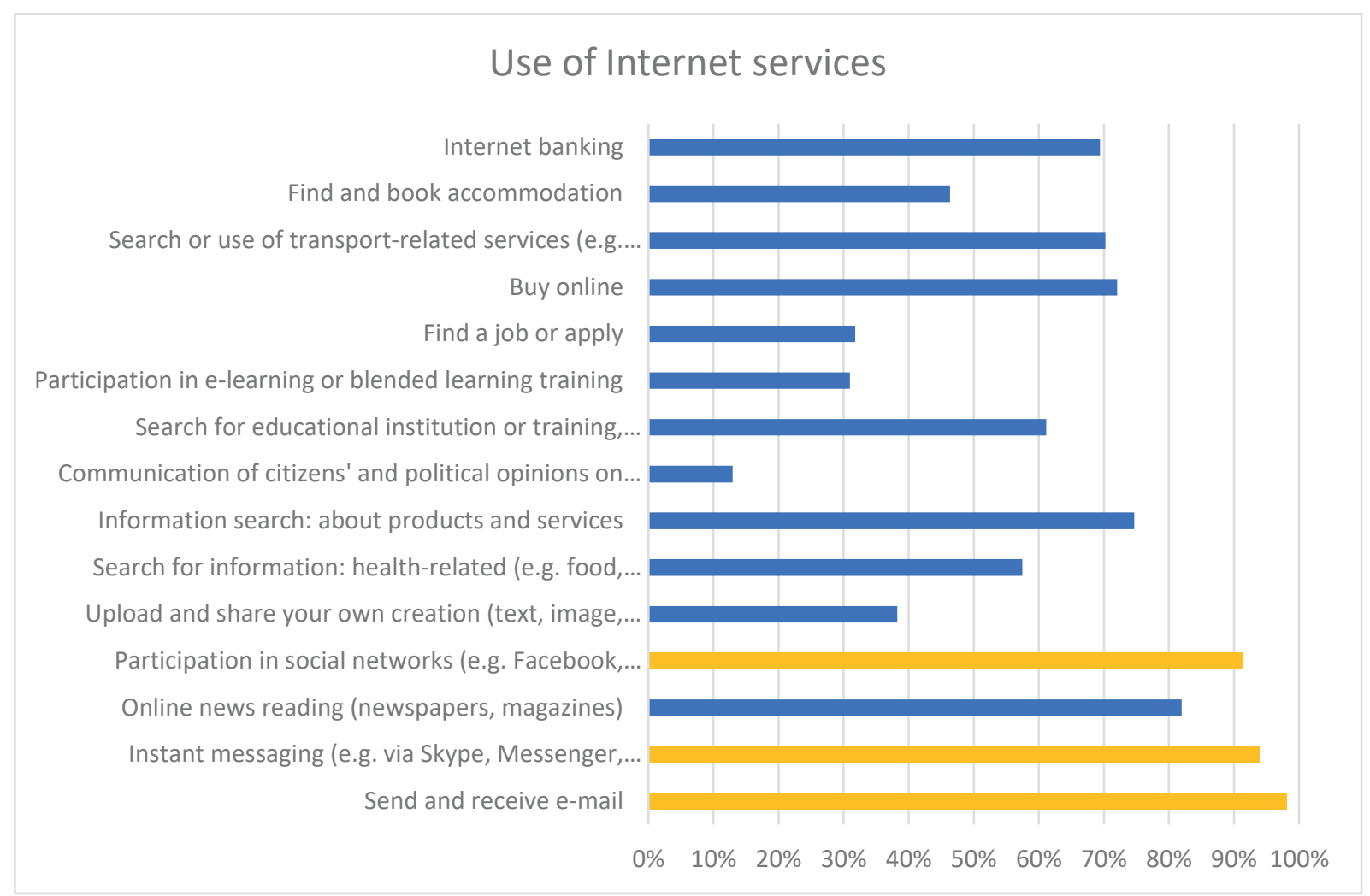

Figure 2: Using Internet Services as a citizen

Source: own edition based on questionnaire data ${ }^{14}$

Students have an ID for e-administration (Client Gate 98.6\%). One in five students has an e-ID card but they are not using it due to the lack of a card reader.

Use of online public services is lagging behind. Most of the time they just get information on the web pages or download, print forms. Form completion and submission are low.

The most used services were the higher education enrolment procedure ${ }^{15}$ and the proactive tax return, but they also requested documents, certificates and queried databases (real estate, motor vehicle, social security). Respondents rated the quality of eGovernment services on a scale from 1 to 7 points. Although services are generally rated as good ( 5 points on average), the need for future re-use of services is lower (4.2 points on average).

\footnotetext{
${ }^{14}$ The values are higher than the DESI data because the respondents are students.

${ }^{15}$ Electronic administration is mandatory
} 


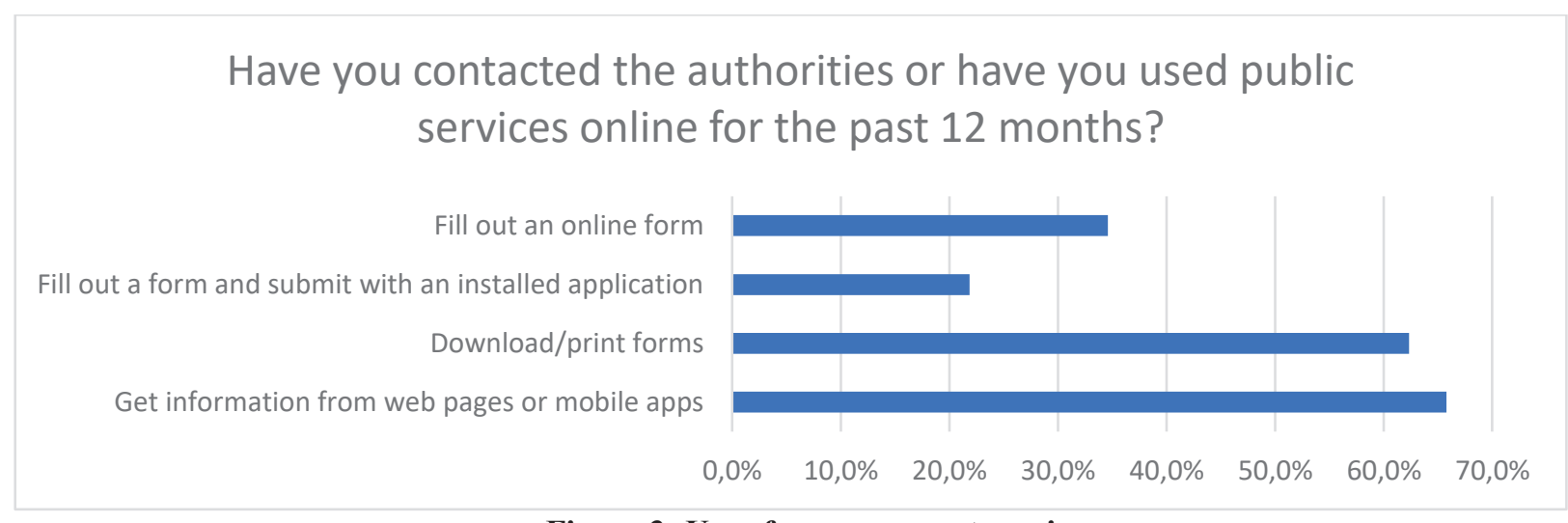

Figure 3: Use of e-government services

Source: own edition based on questionnaire data ${ }^{16}$

Although the questionnaire respondents had a high level of technical background, they only had basic digital skills (mostly searching for information, copying, moving, deleting folders, basic word processing, and spreadsheeting). The level of e-public services was rated better (5.5 point) assessed by those who, by their own admission, had little basic capabilities or no such skills.

\section{Summary and recommendations}

Evaluating the performance of eGovernment at international level is also a challenge. The main objective of the European index systems presented in this study is to assess the performance levels of the Member States, providing guidance for further development. Most reports provide a snapshot of the examined period (or previous period) based on aggregate metrics. At the same time, it is a problem to follow longer-term developments due to changes in measurement methods and indicators.

It can be stated that Hungary is lagging behind in several areas besides continuous development. The positive impact of developments that have already been implemented or are ongoing (e.g. eadministration default, introduction of the Electronic Health Service Space, launch of a new personalized administration platform, Digital Welfare Program) are expected in the coming years.

The student survey data so far indicate that the prerequisites (Internet access, tools) for using e-public services are available, and Internet services are also used regularly. There would be a need to develop digital and administrative skills, digital public service knowledge (e-citizen knowledge). Experience has shown that most people are not even familiar with e-administration options or are too complicated for them, so they prefer to do their administration in person.

Once the legal framework and infrastructure are in place, another challenge is to encourage and prepare the client side to use the services.

Further research is needed to determine the impact of external factors affecting national performance (user characteristics, administrative characteristics and characteristics of the digital environment).

\footnotetext{
${ }^{16}$ The values are higher than the DESI data because the respondents are students.
} 


\section{References}

[1] Bellresearch, 2018. A digitális ökoszisztéma méröszámainak pontositása. Kutatási jelentés a Kormányzati Informatikai Fejlesztési Ügynökség és a Digitális Jólét Program számára. Budapest

[2] BOJTOR, A. and BOZSÓ, G., 2019. Kitekintés a közigazgatás-fejlesztés nemzetközi mérhetőségére. In: A jó állam mérhetősége III.. Budapest: Dialóg Campus Kiadó, pp. 271-294.

[3] CAPGEMINI et al., 2019. eGovernment Benchmark 2019. Empowering Europeans through trusted digital public services. Luxembourg: Directorate General for Communications Networks, Content and Technology.

[4] Commission of the European Communities, 2007. Communication from the Commission to the spring European Council - Strategic Report on the renewed Lisbon strategy for growth and jobs: launching the new cycle (2008-2010) - Keeping up the pace of change COM/2007/0803 final. Brussels

[5] Commission of the European Communities, 2007. Communication from the Commission to the European Parliament, the Council, the European Economic and Social Committee and the Committee of the Regions - Proposal for a Community Lisbon Programme 2008 - 2010 COM/2007/0804 final. Brussels

[6] CSEH, G., 2019. Digitális Gazdaság és Társadalom Index - Magyarország Európai Uniós teljesitménye a digitális világban. Miskolc

[7] CSÓTÓ, M., 2019. Mérni annyi, mint tudni? Az elektronikus közigazgatás közösségi méröszámairól. Vezetéstudomány / Budapest Management Review, 50(2). kötet, pp. 14-31.

[8] eGovernment working group, 2001. eGovernment indicators for benchmarking eEurope. European Comission.

[9] European Commission, 1999. eEurope - An information society for all. Lisbon

[10] European Commission, 2000. eEurope 2002 - An information society for all. COM/2000/0330 final ed. Brussels

[11] European Commission, 2000. Lisbon European Council 23 and 24 March Presidency Conclusion. [Online] Available at: https://www.europarl.europa.eu/summits/lis1_en.htm\#

[12] European Commission, 2002. eEurope 2005 - An information society for all. An Action Plan to be presented in view of the Sevilla European Council, 21/22 June 2002. Brussels

[13] European Commission, 2005. Communication to the Spring European Council - Working together for growth and jobs - A new start for the Lisbon Strategy - Communication from President Barroso in agreement with Vice-President Verheugen \{SEC(2005) 192\} \{SEC(2005) 193 \} COM/2005/0024 final. Brussels 
[14] European Commission, 2005. i2010 - A European Information Society for growth and employment. Brussels

[15] European Commission, 2010. A Digital Agenda for Europe. COM(2010) 245. Brussels

[16] European Commission, 2010. Europe 2020: A strategy for smart, sustainable and inclusive growth. COM(2010) 2020 final. Brussels

[17] European Commission, 2012. eGovernment Benchmark Framework 2012-2015 - Method paper. Directorate General for Communications Networks, Content and Technology.

[18] European Commission, 2012. The Digital Agenda for Europe - Driving European growth digitally COM(2012) 784 final. Brussels

[19] European Commission, 2015. A Digital Single Market Strategy for Europe COM(2015) 192 final. Brussels

[20] European Commission, 2015. eGovernment Benchmark Framework 2012-2015 - Method Paper Update. s.1.:DG Communications Networks, Content \& Technology.

[21] European Commission, 2015. Monitoring the Digital Economy \& Society 2016 - 2021. DG Communications Networks, Content \& Technology.

[22] European Commission, 2016. eGovernment Benchmark Method - An update for a new cycle 2016-2019. s.1.:DG Communications Networks, Content and Technology.

[23] European Commission, 2017. eGovernment Benchmark Framework 2012-2017 - Method Paper for the benchmarking exercises (comprehensive rules from 2012 to 2017). s.1.:DG Communications Networks, Content \& Technology.

[24] European Commission, 2019. The Digital Economy and Society Index (DESI). [Online] Available at: https://ec.europa.eu/digital-single-market/en/desi

[25] KOK, W., 2004. Facing the challenge: The Lisbon strategy for growth and employment. Belgium: Office for Official Publications of the European Communities.

[26] Ministry of National Development, 2014. National Infocommunication Strategy (2014-2020). Development Strategy of the Infocommunications Sector (2014-2020) v9.0. [Online] Available at: https://www.kormany.hu/download/5/ff/70000/NIS_EN_clear.pdf

[27] MOLNÁR, S., 2007. E-közigazgatás az Európai Unióban. In: Az információs társadalom. Az elmélettöl a politikai gyakorlatig. Budapest: Gondolat - Új Mandátum, pp. 144-168.

[28] National Interoperability Framework Observatory (NIFO), 2020. Digital Government Factsheets. [Online] Available at: https://joinup.ec.europa.eu/node/701912

[29] SAPIR, A. et al., 2004. An Agenda for a Growing Europe: The Sapir Report. Report of an Independent High-Level Study Groupestablished on the initiative of thePresident of the European Commission. Oxford University Press. [Online] Available at: 
https://www.researchgate.net/publication/227467942_An_Agenda_for_a_Growing_Europe_T he_Sapir_Report 